Wayne State University

DigitalCommons@WayneState

National Biofuels Energy Laboratory

Chemical Engineering and Materials Science

$1-1-2010$

\title{
Effects of Preparative Parameters on the Structure and Performance of Ca-La Metal Oxide Catalysts for Oil Transesterification
}

Shuli Yan

Wayne State University, dz3870@wayne.edu

Manhoe Kim

Wayne State University, dv4823@wayne.edu

Siddharth Mohan

Wayne State University, du8794@wayne.edu

Steven O. Salley

Wayne State University, ssalley@wayne.edu

K.Y. Simon Ng

Wayne State University, sng@eng.wayne.edu

\section{Recommended Citation}

Shuli Yan, Manhoe Kim, Siddharth Mohan, Steven O. Salley, K.Y. Simon Ng

Effects of preparative parameters on the structure and performance of Ca-La metal oxide catalysts for oil transesterification Applied Catalysis A: General, Volume 373, Issues 1-2, 31 January 2010, Pages 104-111

http: / /dx.doi.org/10.1016/j.apcata.2009.11.001

Available at: http://digitalcommons.wayne.edu/bio_fuel/2 
This article is the author's final version after peer-review. A publisher version (Elsevier) of this article previously appeared in Applied Catalysis A: General (Vol. 373, Iss. 1-2, 2010, p. 104-111).

Journal available at:

http://www.elsevier.com/wps/product/cws home/500856 


\title{
Effects of preparative parameters on the structure and performance of $\mathrm{Ca}$ - La metal oxide catalysts for oil transesterification
}

\author{
S. Yan, M. Kim, Siddharth Mohan, S. O. Salley, and K. Y. Simon Ng \\ Department of Chemical Engineering and Materials Science, Wayne State University, USA
}

\begin{abstract}
The effects of preparative parameters on the surface basicity, composition, and transesterification activities of several Ca-La metal oxide catalysts were investigated. Four different preparation methods: ammonia-ethanol-carbon dioxide precipitation, physical mixing, impregnation, and coprecipitation, were studied. It was found that the ammoniaethanol-carbon dioxide precipitation method resulted in the highest BET specific surface area, base strength and base site concentration. Moreover, catalyst surface composition and basicity are a function of calcination temperature, precipitants, $\mathrm{pH}$, and molar ratio of $\mathrm{Ca}$ to $\mathrm{La}$ in precursor solution, and storage conditions. XRD, XPS, basicity and BET tests revealed that catalyst structure and dispersion of $\mathrm{Ca}$ species strongly influenced the catalyst activity. High surface concentration of $\mathrm{Ca}$ species, strong base strength and high concentration of base sites, and high specific surface area are characteristics of an active transesterification catalyst.
\end{abstract}

Keywords: Biodiesel, Transesterification, Solid base catalyst, Preparation method, Calcination, Precipitant 


\section{Effects of preparative parameters on the structure and performance of Ca- La metal oxide catalysts for oil transesterification}

S. Yan, M. Kim, Siddharth Mohan, S. O. Salley, and K. Y. Simon Ng

\section{Introduction}

Biodiesel, a renewable fuel with similar combustion properties to fossil diesel, is normally produced by transesterification of highly refined oils with short-chain alcohols. Biodiesel can significantly decrease the exhaust emission of $\mathrm{CO}_{2}, \mathrm{SO}_{x}$ and unburned hydrocarbons from motor vehicles [1, 2]. Biodiesel is environmentally beneficial, and therefore, is a promising alternative to fossil diesel [3].

Conventionally, biodiesel is produced by a transesterification process using a homogeneous strong base catalyst such as sodium hydroxide or potassium hydroxide. The strong base catalysts have many advantages such as high activity (complete conversion within one hour) and mild reaction conditions ( $65{ }^{\circ} \mathrm{C}$ and $\left.1 \mathrm{~atm}\right)[4,5]$. However, these homogeneous base catalysts are corrosive and removal of the catalysts from product is not straight forward. In general, a large amount of waste washing water is generated, and a long time is required for phase separation [6, 7]. The use of solid base catalyst can alleviate these problems and thus, recently there is an increased interest in the development of a highly active solid base catalyst for biodiesel production [8, 9].

Some calcium-containing catalysts were reported to be active in oil transesterification with methanol [10-13]. Several traditional methods have been described for the preparation of calciumcontaining catalysts. Albuquerque et al. [14] prepared a series of $\mathrm{CaO}$ catalysts supported on mesoporous silica using an impregnation method. Zhu et al. [15] prepared a solid super base by dipping $\mathrm{CaO}$ in ammonium carbonate solution. Kawashima et al. [16] produced $\mathrm{CaTiO}_{3}, \mathrm{CaMnO}_{3}, \mathrm{Ca}_{2} \mathrm{Fe}_{2} \mathrm{O}_{5}, \mathrm{CaZrO}_{3}$, and $\mathrm{Ca}_{-} \mathrm{CeO}_{2}$ catalysts using a physical mixing method. Ngamcharussrivichai et al. [17] and Wang et al. [18] used precipitation methods to prepare solid base catalysts. However, all these reported calcium-containing catalysts showed much lower activity than a conventional homogeneous $\mathrm{NaOH}$ catalyst. Thus, it is desirable to maximize the surface concentration of active catalytic active site $[13,19]$. It has been reported that high-loading of active components cannot be easily obtained using an impregnation method [20, 21]. High-loading of active components can be obtained using physical mixing [18, 20]. A major drawback of the physical mixing method is low crystallinity of the catalyst which has a negative effect on catalytic activity [22]. Furthermore, a high-loading catalyst generally result in a low specific surface area, and thus low surface concentration of catalytic sites for transesterification [23, 24]. Precipitation methods 
show promise to obtain a high concentration of active catalytic sites [25, 26], however, there are very few reports in relation to the effects of precipitants and preparation process on the structure of $\mathrm{Ca}^{-}$ based solid catalysts and their performance in oil transesterification with methanol. Ngamcharussrivichai et al [17] prepared $\mathrm{Ca}$ and $\mathrm{Zn}$ mixed oxide catalysts using $\mathrm{Na}_{2} \mathrm{CO}_{3}$ as precipitant. Wang et al [18] prepared $\mathrm{CaO}-\mathrm{ZrO}_{2}$ catalysts using ammonia solution as precipitant. Since total deposition of metal ions is important [19, 27], it is apparent that a single precipitant cannot effectively precipitate all metal ions in solution. The effects of multiple precipitants on the structure and performance of Ca-base catalyst have not been reported. The objective of this study is to develop a multistep precipitation process to prepare a $\mathrm{CaO}-\mathrm{La}_{2} \mathrm{O}_{3}$ based catalyst with a relatively high base strength, basicity, specific surface area and site concentration. A new precipitation process utilizing ammonia solution (as base precipitant), carbon dioxide (as acid precipitant) and ethanol (as neutral precipitant) was developed. The Ca3La1 catalyst prepared by this novel method was compared with those prepared by physical mixing, impregnation, and co-precipitation methods. The effects of catalyst preparative parameters on catalytic activities, such as $\mathrm{pH}$ value of precursor metal salt solution, molar ratio of $\mathrm{Ca}$ to La and calcination temperature were investigated. For solid base catalyst, proper storage conditions are important for maintaining a high activity [28]. Thus, the effects of adsorbed triglyceride, methanol, $\mathrm{CO}_{2}$ and $\mathrm{H}_{2} \mathrm{O}$ on the activities of $\mathrm{CaO}-\mathrm{La}_{2} \mathrm{O}_{3}$ based catalysts were evaluated.

\section{Experimental}

\subsection{Materials}

Soybean oil (0.02\% of free fatty acids (FFA) and $0.02 \%$ of water) was purchased from Costco warehouse (Detroit, MI). Methanol (0.03 \% water) was obtained from Mallinckrodt Chemicals (Phillipsburg, NJ). Calcium oxide (99.9\%), lanthanum oxide (99.9\%), calcium acetate hydrate (98\%), lanthanum nitrate hydrate (98\%), ethanol (95\%) and ammonia (99\%) are of analysis grade, and were purchased from Sigma-Aldrich Company (St. Louis, MO).

\subsection{Catalyst Preparation}

$\mathrm{CaO}-\mathrm{La}_{2} \mathrm{O}_{3}$ series catalysts were prepared by four different methods.

\subsubsection{Ammonia-ethanol-carbon dioxide precipitation method:}

Appropriate amounts of $2 \mathrm{M} \mathrm{La}\left(\mathrm{NO}_{3}\right)_{3}$ and $1 \mathrm{M} \mathrm{Ca}(\mathrm{Ac})_{2}$ solutions were mixed, with $\mathrm{pH}$ value of the mixture adjusted to 9.0 with a $6 \mathrm{M}$ ammonia solution. Stepwise addition of $100 \mathrm{ml}$ of ethanol was made every 30 minutes (repeated four times) to the boiling mixture solution to promote initial precipitate formation. This was followed by bubbling of $30 \mathrm{~mL} / \mathrm{min}$ of $\mathrm{CO}_{2}(10$ (v) \% in air) for 5 minutes at 30 minute intervals to form carbonate precipitate (repeated six times). The $\mathrm{pH}$ value of 
the precursor solution was maintained at 9.0 by ammonia solution throughout the whole process.

The precipitate was filtered and washed with $100 \mathrm{~mL}$ of $75 \%$ ethanol solution, dried at $150{ }^{\circ} \mathrm{C}$ for 12 hours, calcined at $430{ }^{\circ} \mathrm{C}$ for $1 \mathrm{hr}$, then at $780{ }^{\circ} \mathrm{C}$ for 8 hours. This catalyst was labeled as Ca3La1. When only $\mathrm{Ca}(\mathrm{Ac})_{2}$ solution was used, the Ca-containing catalyst was labeled as $\mathrm{CaO}$; and when only $\mathrm{La}\left(\mathrm{NO}_{3}\right)_{3}$ solution was used, the La-containing catalyst was labeled as $\mathrm{La}_{2} \mathrm{O} 3$.

When only ammonia solution was used as precipitant, the prepared catalyst was labeled as Ca3La1- $\mathrm{NH}$. Analogously, the catalysts were labeled as $\mathrm{Ca} 3 \mathrm{La} 1-\mathrm{CH}_{3} \mathrm{CH} 2 \mathrm{OH}$ and $\mathrm{Ca} 3 \mathrm{La} 1-\mathrm{CO}_{2}$ when only ethanol or $\mathrm{CO}_{2}$ was used, respectively.

\subsubsection{Physical mixing method}

Eighteen grams of $\mathrm{CaO}$ and $33 \mathrm{~g}$ of $\mathrm{La}_{2} \mathrm{O}_{3}$ were physically mixed with $50 \mathrm{~g}$ of distilled water and ground in a mortar. This mixture was then dried at $100{ }^{\circ} \mathrm{C}$ for 10 hour and, calcined at $780{ }^{\circ} \mathrm{C}$ for 8 hours. This catalyst was labeled as $\mathrm{CaO}-\mathrm{La}_{2} \mathrm{O}_{3}$.

\subsubsection{Impregnation method}

$\mathrm{La}_{2} \mathrm{O}_{3}$ powder was impregnated with an appropriate amount of $1 \mathrm{M} \mathrm{Ca}(\mathrm{Ac})_{2}$ solutions, followed by drying at $100{ }^{\circ} \mathrm{C}$ for 10 hours, calcined at $780{ }^{\circ} \mathrm{C}$ for 8 hours. The process was repeated again to obtain the desired $\mathrm{CaO}$ loading. This catalyst was labeled as $\mathrm{CaO} / \mathrm{La}_{2} \mathrm{O} 3$.

\subsubsection{Co-precipitation method}

Appropriate amounts of $1 \mathrm{M} \mathrm{Ca}\left(\mathrm{NO}_{3}\right)_{2}, 2 \mathrm{M} \mathrm{La}\left(\mathrm{NO}_{3}\right)_{3}$ and $1 \mathrm{M} \mathrm{Na} 2 \mathrm{CO}_{3}$ solutions were mixed with vigorous stirring. After the precipitate was formed, it was filtered and washed with distilled water. The solid precipitate were then dried at $100{ }^{\circ} \mathrm{C}$ for 10 hours, and calcined at $780{ }^{\circ} \mathrm{C}$ for 8 hours. This catalyst was labeled as $\mathrm{La}_{2} \mathrm{O}_{3} \cdot \mathrm{CaO}$.

All catalysts were activated at $780{ }^{\circ} \mathrm{C}$ for 1 hour in pure $\mathrm{N}_{2}(30 \mathrm{~mL} / \mathrm{min})$ before any kinetic study.

\subsection{Catalyst Characterization}

The Hammett indicator method was used to determine the basic strength of the catalyst [28, 30]. Basic strength was expressed by an acidity function $\left(\mathrm{H}_{-}\right)$defined by Eq. (1), where [BH-] and [B-] are the concentrations of the indicator and its conjugated base, respectively, and $\mathrm{pK} \mathrm{BH}$ is the logarithm of the dissociation constant of the indicator used:

$$
\mathbf{H}_{-}=p K_{\mathrm{BH}}+\log \frac{\left[\mathrm{B}^{-}\right\rfloor}{[\mathrm{BH}]}
$$

The indicators used were as follows: neutral red $(\mathrm{pKBH}=6.8)$, bromothymol blue $(\mathrm{pKBH}=7.2)$, phenolphthalein $(\mathrm{pK} \mathrm{BH}=9.8), 2,4$-dinitroaniline $(\mathrm{pK} \mathrm{BH}=15.0)[31,32]$. Basicity was measured 
by the method of Hammett indicator-benzene carboxylic acid (0.02 mol/l anhydrous methanol solution) titration [33].

The specific surface area of the catalysts were determined by a Micromeritics model ASAP 2010 surface area analyzer (North Huntingdon, PA) based on nitrogen adsorption/desorption isotherms acquired at $77.2 \mathrm{~K}$ using a $30 \mathrm{~s}$ equilibrium interval. The surface area was computed using the BET (Brunauer-Emmett-Teller) model. All catalyst samples were degassed at $200{ }^{\circ} \mathrm{C}$ for $5 \mathrm{~h}$ prior to analysis to remove any adsorbed molecules from the pores and surfaces.

Thermal decomposition of the catalyst was evaluated by thermogravimetric analysis/differential thermal analysis (TG/DTG) carried out on a Perkin Elmer Pyris-1 (Waltham, MA) operating under a flow of nitrogen $(30 \mathrm{~mL} / \mathrm{min})$ and at a $10{ }^{\circ} \mathrm{C} / \mathrm{min}$ heating rate from room temperature to $1273 \mathrm{~K}$.

Powder X-ray diffraction (XRD) patterns were taken with a Rigaku RU2000 rotating anode powder diffractometer (Woodlands, TX) equipped with $\mathrm{CuK} \alpha$ radiation $(40 \mathrm{kV}, 200 \mathrm{~mA})$, over a $2 \theta$ range of $20^{\circ}-80^{\circ}$, with a step size of $0.02^{\circ}$ and a scanning speed of $5^{\circ} / \mathrm{min}$.

Energy dispersive spectrometry (EDS) was performed with an Hitachi S-2400 Scanning Electron Microscope (San Jose, CA). Maximum operating voltage used was $25 \mathrm{kV}$.

\subsection{Biodiesel Reactions and Product Analysis}

Erlenmeyer flasks $(25 \mathrm{~mL})$ containing oil, methanol, and catalysts were used as batch reactors. In most studies, $10.0 \mathrm{~g}$ of soybean oil, $7.6 \mathrm{~g}$ of methanol, and $0.5 \mathrm{~g}$ of activated oxide catalyst were put into a flask. Flasks containing the reactant mixture were heated in a shaking bath (Series 25 incubator, New Brunswick Scientific Co.) maintained at $58{ }^{\circ} \mathrm{C}$ and shaken with a speed of $450 \mathrm{rpm}$. The tube reactor has a dimension of $20 \mathrm{~mm}$ i.d. • $355 \mathrm{~mm}$ length in which $8 \mathrm{~g}$ of Zn3La1 catalyst was packed. Reactants were premixed in a beaker and then pumped into the top of the vertically oriented reactor. The flow rate was fixed at $0.2 \mathrm{~mL} / \mathrm{min}$ (Chrom. Tech. Inc., Apple Valley, MN); reaction temperature was held at $58^{\circ} \mathrm{C}$ in a water bath (PolyScience Inc., Warrington, PN); reaction pressure was around 1 atm; resident time was 120 minutues; molar ratio of methanol to oil varied from 15:1.

The concentrations of FAME in the samples were quantified by using a GC-MS (Clarus 500 GCMS, Perkin-Elmer) with a capillary column (Rtx-WAX Cat. No.12426). Ethyl arachidate (Nu-Chek Prep Inc, Elysian, Minnesota) was used as an internal standard. Water content was analyzed using a Brinkman/Metrohm 831 KF Coulometer (Westbury, NY) according to ASTM D 6304-00. FFA concentration was determined using a Brinkman/Metrohm 809 titrando (Westbury, NY) according to ASTM D 664.

\section{Results and Discussion}




\subsection{Effect of preparation method}

The XRD spectrum of Ca-La metal oxide catalysts which were prepared by four different preparation methods were shown in Figure 1. For the Ca3La1 catalyst, $\mathrm{Ca}(\mathrm{OH})_{2}$ and $\mathrm{La}(\mathrm{OH})_{3}$ phases were identified, indicating that Ca3La1 consisted of a mixture of each hydroxide. For

$\mathrm{CaO} / \mathrm{La}_{2} \mathrm{O}_{3}$, only the $\mathrm{La}(\mathrm{OH})_{3}$ phase was identified and no Ca crystalline peaks were detected, even though the EDS results (Table 1) show that this catalyst had a bulk Ca to La ratio of 0.3. The $\mathrm{XRD}$ spectrum of the $\mathrm{CaO} / \mathrm{La}_{2} \mathrm{O}_{3}$ also shows that there was a slight shift of the peaks at $27.2^{\circ}$ and $28.0^{\circ}$ which corresponded to the $(1,1,0)$ and $(1,0,1)$ planes of $\mathrm{La}(\mathrm{OH})_{3}$, respectively.

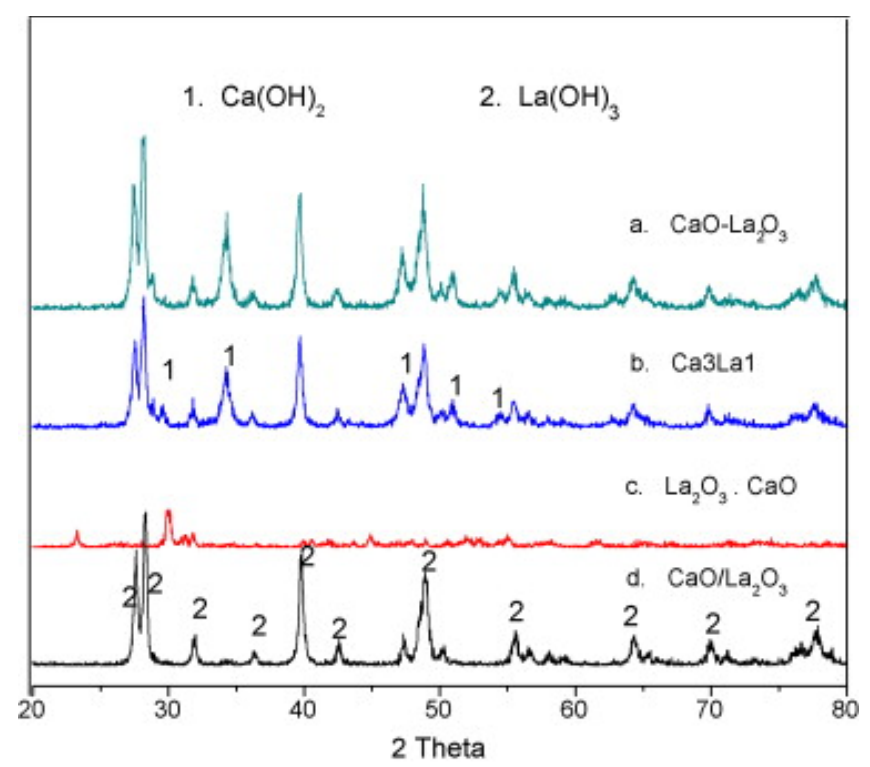

Fig. 1. XRD spectrum of Ca3La1, $\mathrm{CaO} / \mathrm{La}_{2} \mathrm{O}_{3}, \mathrm{La}_{2} \mathrm{O}_{3} \cdot \mathrm{CaO}$, and $\mathrm{CaO}-\mathrm{La}_{2} \mathrm{O}_{3}$.

These shifts suggest that La3+ions in the host lattice were partially substituted by Ca2+ions [34]. For $\mathrm{La}_{2} \mathrm{O}_{3} \cdot \mathrm{CaO}$, there were no evident diffraction patterns of $\mathrm{Ca}$ or La species suggesting a highly amorphous nature of this material [35]. For CaO-La2O3, the physically mixed sample, both $\mathrm{Ca}(\mathrm{OH})_{2}$ and $\mathrm{La}(\mathrm{OH})_{3}$ phases were found. However, the half-width of peaks of $\mathrm{Ca}(\mathrm{OH})_{2}$ and $\mathrm{La}(\mathrm{OH})_{3}$ phases were smaller than those of the Ca3La1 catalyst, indicating that the crystal size of $\mathrm{CaO}-\mathrm{La}_{2} \mathrm{O}_{3}$ was bigger than Ca3La1. The XRD measurements suggest that calcium can exists as segregated $\mathrm{Ca}(\mathrm{OH})_{2}$ crystal (as in $\mathrm{Ca} 3 \mathrm{La} 1$ and $\mathrm{CaO}-\mathrm{La}_{2} \mathrm{O}_{3}$ ), incorporated into the La species lattice (as in $\mathrm{CaO} / \mathrm{La}_{2} \mathrm{O}_{3}$ ), or amorphous form (as in $\mathrm{La}_{2} \mathrm{O}_{3} \cdot \mathrm{CaO}$ ), as a result of different preparation procedures.

It has been reported that the base sites over heterogeneous catalysts are active centers for transesterification [36,37]. Thus, it is interesting to correlate the effects of base strength and basicity of the catalysts on activity. As indicated in Table 1, Ca3La1 shows the highest value in base strength $(9.8<\mathrm{H}-<15)$. Moreover, the total basicity of the catalysts is in the order of: Ca3La1 > 
$\mathrm{CaO} / \mathrm{La}_{2} \mathrm{O}_{3}>\mathrm{CaO}-\mathrm{La}_{2} \mathrm{O}_{3}>\mathrm{La}_{2} \mathrm{O}_{3} / \mathrm{CaO}$. As discussed before, $\mathrm{Ca} 3 \mathrm{La} 1$ exhibits the best transesterification activity among these catalysts.

The catalysts prepared by traditional methods have low BET surface areas $(<10 \mathrm{~m} / \mathrm{g})$ as compared to Ca3La1 (62.6 $\mathrm{m}^{2} / \mathrm{g}$, Table 1). XPS and EDS results show that surface atomic molar ratios of $\mathrm{Ca}$ to $\mathrm{La}$ for $\mathrm{Ca} 3 \mathrm{La} 1, \mathrm{CaO} / \mathrm{La}_{2} \mathrm{O}_{3}$ and $\mathrm{La}_{2} \mathrm{O}_{3} \cdot \mathrm{CaO}$ catalysts are higher than bulk ones.

This suggests that the ammonia-ethanol-carbon dioxide precipitation method, impregnation method and co-precipitation method can promote Ca dispersion on the surface of the catalyst.

Table 1. BET specific surface area, surface atomic ratio of $\mathrm{Ca}$ to $\mathrm{La}$, bulk molar ratio of $\mathrm{Ca}$ to $\mathrm{La}$, and basicity of $\mathrm{Ca}$ La1, $\mathrm{CaO} / \mathrm{La}_{2} \mathrm{O}_{3}, \mathrm{La}_{2} \mathrm{O}_{3} \cdot \mathrm{CaO}, \mathrm{CaO}-\mathrm{La}_{2} \mathrm{O}_{3}$.

\begin{tabular}{|c|c|c|c|c|c|c|c|c|}
\hline Catalyst & Preparation & $\begin{array}{l}\text { Bulk atomic } \\
\text { ratio of } \mathrm{Ca}\end{array}$ & $\begin{array}{l}\text { Specific } \\
\text { surface area }\end{array}$ & $\begin{array}{l}\text { Surface } \\
\text { atomic ratio }\end{array}$ & \multicolumn{4}{|c|}{ Basicity $(\mathrm{mmol} / \mathrm{g})$} \\
\hline & & & & & $\begin{array}{l}6.8<\mathrm{H}_{-} \\
<7.2\end{array}$ & $\begin{array}{l}7.2<\mathrm{H}_{-} \\
<9.8\end{array}$ & $\begin{array}{l}9.8<H_{-} \\
<15\end{array}$ & $\begin{array}{l}\text { Total } \\
\text { basicit } \\
\text { y } \\
\text { (mmol }\end{array}$ \\
\hline Ca3La1 & $\begin{array}{l}\text { Ammonia- } \\
\text { ethanol- } \\
\text { carbon } \\
\text { dioxide } \\
\text { precipitation } \\
\text { method }\end{array}$ & 3.5 & 62.6 & 4.2 & 2.0 & 10.4 & 1.2 & 13.6 \\
\hline $\mathrm{CaO} / \mathrm{La}_{2} \mathrm{O}_{3}$ & $\begin{array}{l}\text { Impregnation } \\
\text { method }\end{array}$ & 0.3 & 5.3 & 2.7 & 5.1 & 3.4 & - & 8.5 \\
\hline $\mathrm{La}_{2} \mathrm{O}_{3} \cdot \mathrm{CaO}$ & $\begin{array}{l}\text { Co- } \\
\text { precipitation } \\
\text { method }\end{array}$ & 0.4 & 9.9 & 0.7 & 0.8 & - & - & 0.8 \\
\hline $\mathrm{CaO}-\mathrm{La}_{2} \mathrm{O}_{3}$ & $\begin{array}{l}\text { Physical } \\
\text { mixing } \\
\text { method }\end{array}$ & 3.5 & 6.2 & 3.1 & 3.8 & 2.1 & - & 5.9 \\
\hline
\end{tabular}

The catalytic performance of Ca-La based catalysts prepared by different preparation methods is presented in Figure 2. The FAME yields after one hour for these catalysts were between that achieved by homogeneous $\mathrm{NaOH}$ or $\mathrm{H}_{2} \mathrm{SO}_{4}$ catalysts. Ca3La1 needed about 60 minutes to get to the highest FAME yield (95.3\%), which shows a similar catalytic activity to $\mathrm{NaOH}$ and is higher than $\mathrm{CaO} / \mathrm{La}_{2} \mathrm{O}_{3}, \mathrm{CaO}-\mathrm{La}_{2} \mathrm{O}_{3}$ and $\mathrm{La}_{2} \mathrm{O}_{3} \cdot \mathrm{CaO}$. The catalytic activity trend of $\mathrm{Ca} 3 \mathrm{La} 1, \mathrm{CaO} / \mathrm{La}_{2} \mathrm{O}_{3}, \mathrm{CaO}^{-}$ $\mathrm{La}_{2} \mathrm{O}_{3}$ and $\mathrm{La}_{2} \mathrm{O}_{3} \cdot \mathrm{CaO}$ parallels the variability of total basicity in Table 1 ; i.e. the higher the 
basicity, the higher the activity of catalyst, which is in good agreement with early studies [13, 38, 39]. The effect of catalyst components was also studied. Using an ammoniaethanol-carbon dioxide precipitation method, binary metal oxides catalyst, Ca3La1, single CaOcontaining, and single La2O3-containing catalysts were prepared. Figure 2 shows that binary metal oxides catalyst has a higher activity than pure metal oxides. Our previous study shows that there was a strong interaction between $\mathrm{Ca}$ and La species in the binary catalyst prepared by the ammonia-ethanolcarbon dioxide precipitation method, which resulted in high basicity, high BET surface area and high catalytic activity in oil transesterification [39].

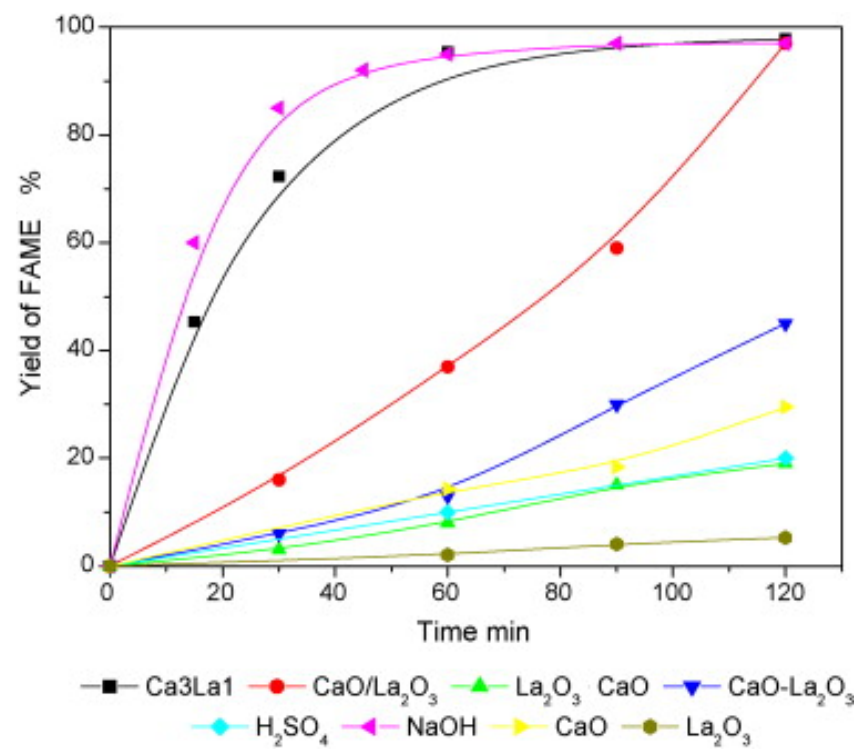

Fig. 2. Transesterification activities of $\mathrm{Ca} 3 \mathrm{La}^{(1)}, \mathrm{CaO} / \mathrm{La}_{2} \mathrm{O}_{3}{ }^{(1)}, \mathrm{La}_{2} \mathrm{O}_{3} \cdot \mathrm{CaO}^{(1)}, \mathrm{CaO}-\mathrm{La}_{2} \mathrm{O}_{3}^{(1)}, \mathrm{CaO}^{(1)}, \mathrm{La}_{2} \mathrm{O}_{3}(1)$, $\mathrm{H}_{2} \mathrm{SO}_{4}{ }^{(2)}$ and $\mathrm{NaOH}^{(3)}$. Reaction conditions: (1) $10 \mathrm{~g}$ of soybean oil, $7.6 \mathrm{~g}$ of methanol, $0.5 \mathrm{~g}$ of catalyst and $65{ }^{\circ} \mathrm{C}$; (2) $20 \mathrm{~g}$ of soybean oil, $7.3 \mathrm{~g}$ of methanol, $0.6 \mathrm{~g}$ of $\mathrm{H}_{2} \mathrm{SO}_{4}$ and $65{ }^{\circ} \mathrm{C}$; and (3) $20 \mathrm{~g}$ of soybean oil, $4.5 \mathrm{~g}$ of methanol, $0.2 \mathrm{~g}$ of $\mathrm{NaOH}$ and $65^{\circ} \mathrm{C}$.

\subsection{Effect of calcination temperature}

Since the catalyst prepared by the ammonia-ethanol-carbon dioxide precipitation method showed promising activity in oil transesterification, the effects of preparative parameters, such calcination temperature, calcium loading, $\mathrm{pH}$ value, ammonia, $\mathrm{CO}_{2}$ and alcohol addition, and storage conditions, were investigated to optimize the catalyst structure and activities.

Figure 3 is a TG curve of uncalcined Ca3La1. The total weight loss from $50{ }^{\circ} \mathrm{C}$ to $920{ }^{\circ} \mathrm{C}$ was about $87 \%$. The weight loss before $200{ }^{\circ} \mathrm{C}$ was about $10 \%$ which corresponded to the desorption of physically adsorbed molecules $\left(\mathrm{H}_{2} \mathrm{O}\right.$ and $\left.\mathrm{CO}_{2}\right)$ [40]. The weight loss from $300 \sim 430{ }^{\circ} \mathrm{C}$ was about 70 $\%$ which can be attributed to the decomposition of $\mathrm{Ca}(\mathrm{OH})_{2}, \mathrm{La}(\mathrm{OH})_{3}$ and $\mathrm{Ca}\left(\mathrm{OCH}_{2} \mathrm{CH}_{3}\right)_{2}[41,42]$. 
Lastly, the weight loss at $700 \sim 780{ }^{\circ} \mathrm{C}$ was considered to be the decomposition of carbonate salts such as $\mathrm{CaCO}_{3}$ and $\mathrm{La}_{2} \mathrm{CO}_{5}[43,44]$.

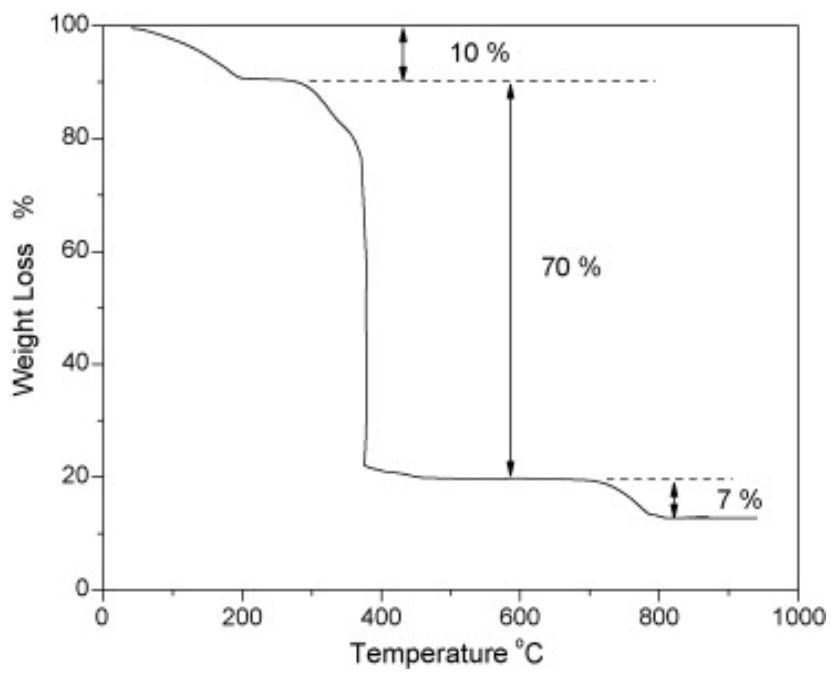

Fig. 3. Weight losses as a function of temperature of uncalcined Ca3La1. Note the three weight loss stages.

Based on the TG curve, the Ca3La1 catalyst was calcined at $300{ }^{\circ} \mathrm{C}, 450{ }^{\circ} \mathrm{C}, 780{ }^{\circ} \mathrm{C}$ and $950{ }^{\circ} \mathrm{C}$ respectively, and the total basicities were measured (Figure 4). It can be observed that the basicity of the catalysts initially increased with the calcination temperature and reached a maximum at $780^{\circ} \mathrm{C}$; but decreased when the calcination temperature exceeded $780^{\circ} \mathrm{C}$. BET surface area in Table 2 shows a similar trend. $780^{\circ} \mathrm{C}$ was considered to be the optimal calcination temperature to obtain a maximum value in both basicity and BET surface area.

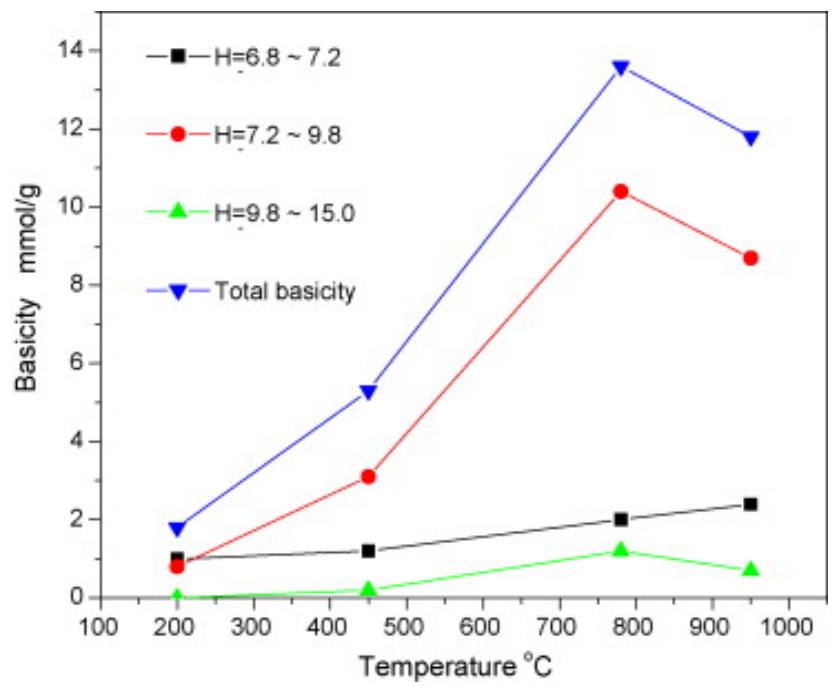

Fig. 4. Basicity of Ca3La1 calcined at different temperature. Note the basicity at $780{ }^{\circ} \mathrm{C}$. 
Table 2.

BET specific surface area, surface atom ratio of Ca to La, binding energy and surface percentages of La, Ca and lattice oxygen.

\begin{tabular}{|c|c|c|c|c|c|c|c|c|c|}
\hline \multirow[t]{2}{*}{$\begin{array}{l}\text { Catalyst calcinations } \\
\text { temperature }\left({ }^{\circ} \mathrm{C}\right)\end{array}$} & \multicolumn{4}{|c|}{ Binding energy $(\mathrm{eV})$} & \multicolumn{3}{|c|}{$\begin{array}{l}\text { Surface percentage } \\
\text { (at.\%) }\end{array}$} & \multirow[t]{2}{*}{$\begin{array}{l}\text { Surface atom } \\
\text { ratio of Ca:La }\end{array}$} & \multirow[t]{2}{*}{$\begin{array}{l}\text { Specific surface } \\
\text { area }\left(\mathrm{m}^{2} / \mathrm{g}\right)\end{array}$} \\
\hline & $\mathrm{La}_{3 \mathrm{~d}}$ & $\mathrm{Ca}_{2 \mathrm{p} 1}$ & $\mathrm{Ca}_{2 \mathrm{p} 2}$ & $\mathrm{O}_{\text {lat }}$ & $\mathrm{O}_{\text {lat }}$ & $\mathrm{Ca}^{2+}$ & $\mathrm{La}^{3+}$ & & \\
\hline 300 & 833.4 & 347.9 & 346.7 & 528.7 & 60.6 & 3.2 & 0.6 & 5.3 & 5.0 \\
\hline 450 & 833.7 & 347.6 & 346.3 & 529.0 & 62.2 & 5.6 & 2.1 & 2.7 & 41.5 \\
\hline 780 & 833.6 & 348.2 & 346.7 & 528.9 & 70.8 & 12.5 & 3.0 & 4.2 & 62.6 \\
\hline 950 & 833.8 & 348.0 & 346.5 & 528.9 & 60.3 & 11.3 & 4.6 & 2.4 & 20.2 \\
\hline
\end{tabular}

The chemical state and surface composition of the catalysts as determined by XPS are shown in Table 2. The binding energy (BE) of La $3 \mathrm{~d} 5 / 2$ remained constant at $833.4 \sim 833.8 \mathrm{eV}$ as calcination temperature increased. The $\mathrm{BE}$ of the two $\mathrm{Ca} 2 \mathrm{P}_{3 / 2}$ components were at $347.6 \sim 348.2 \mathrm{eV}$ for $\mathrm{CaCO}_{3}$ and $346.3 \sim 346.7 \mathrm{eV}$ for $\mathrm{Ca}(\mathrm{OH})_{2}$ species, respectively [45]. Therefore, it appears that the outermost surface layers of the catalyst was carbonated and hydrated. The presence of $\mathrm{CaO}$ can be neglected since the $\mathrm{BE}$ of $\mathrm{Ca}$ in $\mathrm{CaO}$ is below that of $\mathrm{Ca}(\mathrm{OH})_{2}[46]$ and it is not observable in the XPS spectra. The difference between the TG curve, XPS and XRD can be attributed to contact with ambient environment when preparing XPS and XRD samples. $\mathrm{CaO}$ in fresh catalysts could react with $\mathrm{H}_{2} \mathrm{O}$ and $\mathrm{CO}_{2}$ in the air, forming hydroxide and carbonate salts [13]. Thus, there is no characteristic BE line for $\mathrm{CaO}$. Two photoemission lines can be seen for $\mathrm{O} 1 \mathrm{~s}$, which correspond to two distinct oxygen species. The line with low BE (528.7 529.1 eV) was attributed to oxygen ions in the crystal lattice (Olatt); the line $(530.8 \sim 531.2 \mathrm{eV})$ was to the adsorbed oxygen [46, 47]. Crystal lattice oxygen has a strong Lewis base site and it is generally considered as the active center for oil transesterification [48-50]. Table 2 shows that the surface concentration of Olatt and $\mathrm{Ca}^{2+}$ initially increased with calcination temperature, reached the highest value at $780{ }^{\circ} \mathrm{C}$, and then decreased with further increase in temperature. On the other hand, surface $\mathrm{La}^{3+}$ kept increasing with calcination temperature.

The effect of calcination temperature on the catalytic acitivity of Ca3La1 is shown in Figure 5. The catalyst calcined at $780{ }^{\circ} \mathrm{C}$ shows the highest activity and a FAME yield of $95.3 \%$ can be obtained in 
90 minutes. The catalysts calcined at $300{ }^{\circ} \mathrm{C}$ and $450{ }^{\circ} \mathrm{C}$ show low conversions even with an extended reaction time (180 minutes). The catalyst calcined at $950{ }^{\circ} \mathrm{C}$ shows a relatively high activity and a yield of $87.8 \%$ was reached after 180 minutes. Catalyst activity increased with calcination temperature until $780{ }^{\circ} \mathrm{C}$ and then slightly decreased with further temperature increase. The catalyst activities also displayed a similar pattern as basicity (Figure 4), BET surface area and surface $\mathrm{Ca}^{2+}$ and Olatt concentration (Table 2) as a function of calcination temperature.

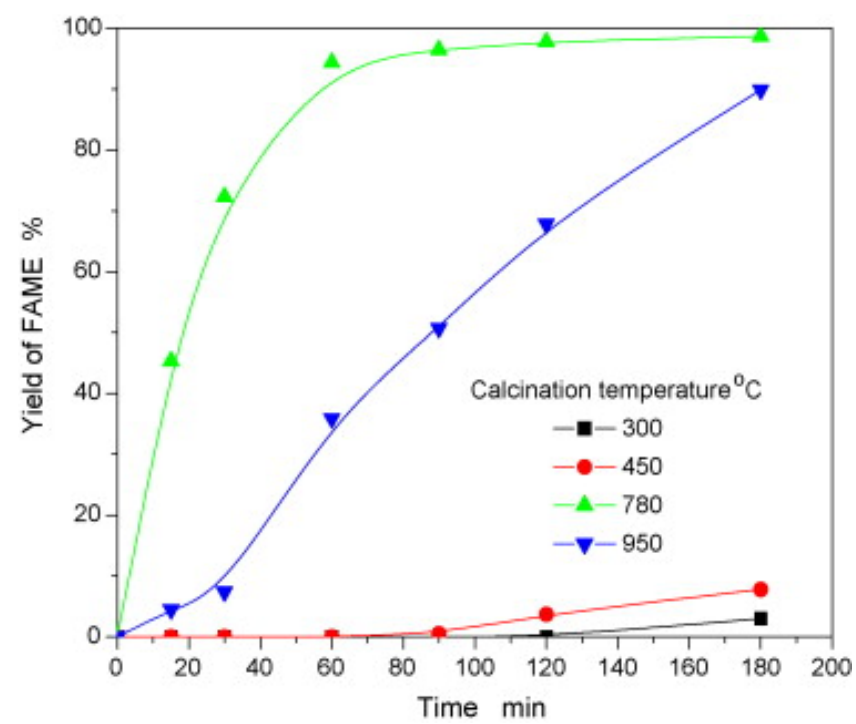

Fig. 5. Yield of FAME based on the catalysts calcined at $300{ }^{\circ} \mathrm{C}, 450{ }^{\circ} \mathrm{C}, 780^{\circ} \mathrm{C}$ and $950{ }^{\circ} \mathrm{C}$. Reaction conditions: $10 \mathrm{~g}$ of soybean oil, $7.6 \mathrm{~g}$ of methanol, $0.5 \mathrm{~g}$ of catalyst and $65^{\circ} \mathrm{C}$.

\subsection{Effect of precipitants}

Table 3 shows the catalyst structure and performance of precipitates of ammonia solution, ethanol and $\mathrm{CO}_{2}$. Using $\mathrm{NH}_{3}$ solution, major precipitates formed were hydroxides such as $\mathrm{La}(\mathrm{OH})_{3}$ and $\mathrm{Ca}(\mathrm{OH})_{2}$ [51]. EDS results show that for Ca3La1-NH3 catalyst, the bulk molar ratio of Ca to La is only 0.4 , which is much lower than that of the original precursor solution ( $3: 1$ of Ca to La). This suggests that $\mathrm{Ca}$ ions present in the original solution were not totally precipitated. BET results show that it has a low specific surface area as compared to Ca3La1. The Hammett indicator results show that it had a low base strength and small amount of basicity. Correspondingly, the FAME yield using Ca3La1-NH3 was only $5.6 \%$ at 90 minutes. Using $\mathrm{CO}_{2}$ as precipitant, carbonates such as $\mathrm{CaCO}_{3}$ and $\mathrm{La}_{2} \mathrm{CO}_{5}$ were formed $[51,52]$. Similar to $\mathrm{Ca}_{3} \mathrm{La}_{1} \mathrm{NH}_{3}, \mathrm{Ca} 3 \mathrm{La} 1-\mathrm{CO}_{2}$ has a low bulk ratio of $\mathrm{Ca}$ to La, low BET surface area, and poor basicity resulting in a poor transesterification activity. When ethanol was used as a precipitant, the major precipitate formed is ethylate [51, 52]. Ca3La1$\mathrm{CH}_{3} \mathrm{CH}_{2} \mathrm{OH}$ exhibited a high specific surface area and a wide distribution of base strength (Table 3). However, it still had a low bulk ratio of Ca2+ to La3+, and low FAME yield (32.1\% after 90 minutes). 
However, as discussed earlier, Ca3La1 catalyst, in which ammonia, ethanol and $\mathrm{CO}_{2}$ were sequentially used as precipitants, had the highest bulk ratio of Ca to La, highest total basicity and highest FAME yield.

Table 3. Bulk molar ratio of Ca to La, BET specific surface area, basicity and yield of FAME of Ca3La1$\mathrm{NH}_{3}$, Ca3La1- $\mathrm{CO}_{2}, \mathrm{Ca} 3 \mathrm{La} 1-\mathrm{CH}_{3} \mathrm{CH}_{2} \mathrm{OH}$ and Ca3La1. Reaction conditions: (1) $10 \mathrm{~g}$ of soybean oil, $7.6 \mathrm{~g}$ of methanol, $0.5 \mathrm{~g}$ of catalyst and $65^{\circ} \mathrm{C}$.

\begin{tabular}{|c|c|c|c|c|c|c|c|}
\hline \multirow[t]{3}{*}{ Catalyst } & \multirow{3}{*}{$\begin{array}{l}\text { Bulk } \\
\text { atomic } \\
\text { ratio of } \mathrm{Ca} \\
\text { to } \mathrm{La}\end{array}$} & \multirow{3}{*}{$\begin{array}{l}\text { Specific } \\
\text { surface } \\
\text { area }\left(\mathrm{m}^{2} / \mathrm{g}\right)\end{array}$} & \multicolumn{4}{|c|}{ Basicity (mmol/g) } & \multirow{3}{*}{$\begin{array}{l}\text { Yield of } \\
\text { FAME } \\
(\%)^{(1)}\end{array}$} \\
\hline & & & \multirow[t]{2}{*}{$6.8<\mathrm{H}_{-}<7.2$} & \multirow[t]{2}{*}{$7.2<\mathrm{H}_{-}<9.8$} & \multirow[t]{2}{*}{$9.8<\mathrm{H}_{-}<15$} & \multirow{2}{*}{$\begin{array}{l}\text { Total } \\
\text { basicity } \\
(\mathrm{mmol} / \mathrm{g})\end{array}$} & \\
\hline & & & & & & & \\
\hline Ca3La1- $\mathrm{NH}_{3}$ & 0.4 & 7.1 & 0.2 & - & - & 0.2 & 5.6 \\
\hline $\mathrm{Ca} 3 \mathrm{La} 1-\mathrm{CO}_{2}$ & 1.6 & 17.4 & 1.1 & 0.7 & - & 1.8 & 27.9 \\
\hline Ca3La1- $\mathrm{CH}_{3} \mathrm{CH}_{2} \mathrm{OH}$ & 1.2 & 66.9 & 1.3 & 7.2 & 1.0 & 9.5 & 32.1 \\
\hline Ca3La1 & 3.5 & 62.6 & 2.0 & 10.4 & 1.2 & 13.6 & 95.3 \\
\hline
\end{tabular}

In this sequential precipitation approach, the addition of $\mathrm{NH}_{3}$ solution (base precipitant) could quickly increase $\mathrm{pH}$ value of the precursor solution. Bubbling in $\mathrm{CO}_{2}$ (acid precipitant) led to the formation of carbonate and slightly decreased the $\mathrm{pH}$ value. Thus, by adjusting the $\mathrm{NH}_{3}$ and $\mathrm{CO}_{2}$ addition, and maintaining the $\mathrm{pH}$ value, Caand Lacan be precipitated in the desired ratio from the precursor solution. There are two possible functions of ethanol. Firstly, during the calcination process the ethylate decomposes and generates a large mount of $\mathrm{CO}_{2}$ and $\mathrm{H}_{2} \mathrm{O}$. These gases may expand the volume of catalyst precursor and lead to the formation of micropores which yields a high specific surface area [27]. Secondly, base strength of $\mathrm{CaO}$ prepared from $\mathrm{CaOCH}_{2} \mathrm{CH}_{3}$ is much higher than that prepared from $\mathrm{CaCO}_{3}$ and $\mathrm{Ca}(\mathrm{OH})_{2}$ [53]. Thus, ethanol may enhance the catalyst basicity. The cooperative effect of the three precipitants leads to a more complete and uniform precipitation and a high specific surface area, base strength and basicity, resulting in a high transesterification activity. 


\subsection{Effect of precursor solutions}

Table 4 shows that if the $\mathrm{pH}$ value was kept at 6.0 or 7.5 , the final catalyst had a relatively low bulk molar ratio of $\mathrm{Ca}$ to La, which suggests that $\mathrm{Ca}^{2+}$ in precursor solution was not fully precipitated. XPS results show that the surface percentage of lattice oxygen, and the $\mathrm{Ca}^{2+}$ and $\mathrm{La}^{3+}$ increased with $\mathrm{pH}$ value of precursor solution, and led to a higher catalytic activity (Figure 6). These findings are consistent with previous studies that $\mathrm{pH}$ value and molar ratio of Ca to La in the precursor solution have an impact on the precipitation process [52, 54].

Table 4. Effects of $\mathrm{pH}$ value of the precursor solution on the bulk molar ratio of Ca to La and surface percentages of $\mathrm{La}, \mathrm{Ca}$ and lattice oxygen.

\begin{tabular}{|c|c|c|c|c|}
\hline \multirow[t]{2}{*}{$\mathrm{pH}$ value of precursor solution } & \multirow[t]{2}{*}{ Bulk atomic ratio of $\mathrm{Ca}$ to $\mathrm{La}$} & \multicolumn{3}{|c|}{ Surface percentage (at.\%) } \\
\hline & & $\mathrm{O}_{\text {lat }}$ & $\mathrm{Ca}^{2+}$ & $\mathrm{La}^{3+}$ \\
\hline $\mathrm{pH} 6.0$ & 2.7 & 48.2 & 3.1 & 0.5 \\
\hline $\mathrm{pH} 7.5$ & 2.8 & 54.1 & 8.2 & 0.8 \\
\hline $\mathrm{pH} 9.0$ & 3.1 & 70.8 & 12.5 & 3.0 \\
\hline
\end{tabular}

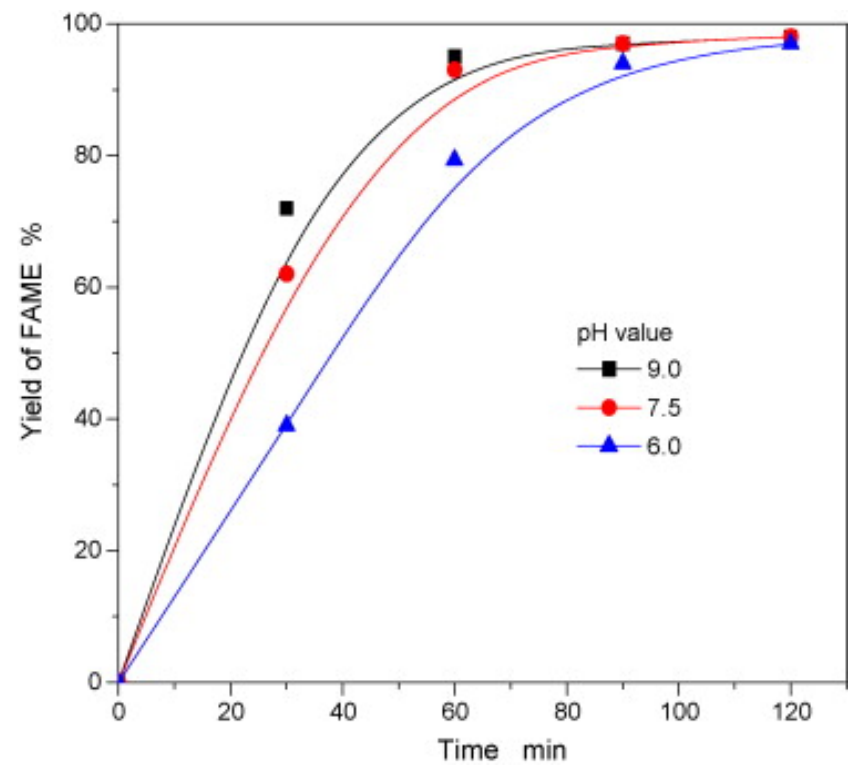

Fig. 6. Yield of FAME based on the catalysts prepared from the precursor solution with 6.0, 7.5 and 9.0 of $\mathrm{pH}$. Reaction conditions: $10 \mathrm{~g}$ of soybean oil, $7.6 \mathrm{~g}$ of methanol, $0.5 \mathrm{~g}$ of catalyst and $65^{\circ} \mathrm{C}$. 
Table 5 shows that molar ratios of Ca to La in the precursor solution were different with those on the catalyst surface. When the molar ratio is 3.0: 1.0 in the precursor solution, the surface percentage of lattice oxygen and total amount of lattice oxygen, and the concentration of $\mathrm{Ca}^{2+}$ and $\mathrm{La}^{3+}$ were highest, and led to the highest catalytic activity (Figure 7). Thus, a basic precursor solution ( $\mathrm{pH}$ 9.0) and 3.0: 1.0 molar ratio of Ca to La in solution were identified as the optimal conditions for the ammonia-ethanol-carbon dioxide precipitation method.

Table 5. Effects of molar ratio of Ca to La of the precursor solution on the surface molar ratio of Ca to La and surface percentages of $\mathrm{La}, \mathrm{Ca}$ and lattice oxygen.

\begin{tabular}{|c|c|c|c|c|c|}
\hline \multirow{2}{*}{$\begin{array}{l}\text { Molar ratio of Ca to La in precursor } \\
\text { solution }\end{array}$} & \multirow{2}{*}{$\begin{array}{l}\text { Surface atomic ratio of } \mathrm{Ca}^{2+} \\
\text { to } \mathrm{La}^{3+}\end{array}$} & \multicolumn{4}{|c|}{ Surface percentage (at.\%) } \\
\hline & & $\mathrm{O}_{\text {lat }}$ & $\mathrm{Ca}^{2+}$ & $\mathrm{La}^{3+}$ & $\begin{array}{l}\text { Total amount of } \mathrm{O}_{\text {lat' }} \mathrm{Ca}^{2+} \\
\text { and } \mathrm{La}^{3+}\end{array}$ \\
\hline $1.0: 0$ & - & 37.4 & 15.3 & - & 52.7 \\
\hline $9.0: 1.0$ & $7.0: 1.0$ & 53.1 & 15.5 & 2.2 & 70.8 \\
\hline $3.0: 1.0$ & $4.2: 1.0$ & 70.8 & 12.5 & 3.0 & 86.3 \\
\hline $1.0: 1.0$ & $1.7: 1.0$ & 69.3 & 8.0 & 4.5 & 81.8 \\
\hline $1.0: 3.0$ & $1.0: 1.2$ & 58.5 & 6.0 & 7.2 & 81.8 \\
\hline $1.0: 9.0$ & $1.0: 2.0$ & 64.6 & 3.4 & 7.1 & 75.1 \\
\hline $0: 1.0$ & - & 51.9 & - & 5.6 & 57.5 \\
\hline
\end{tabular}

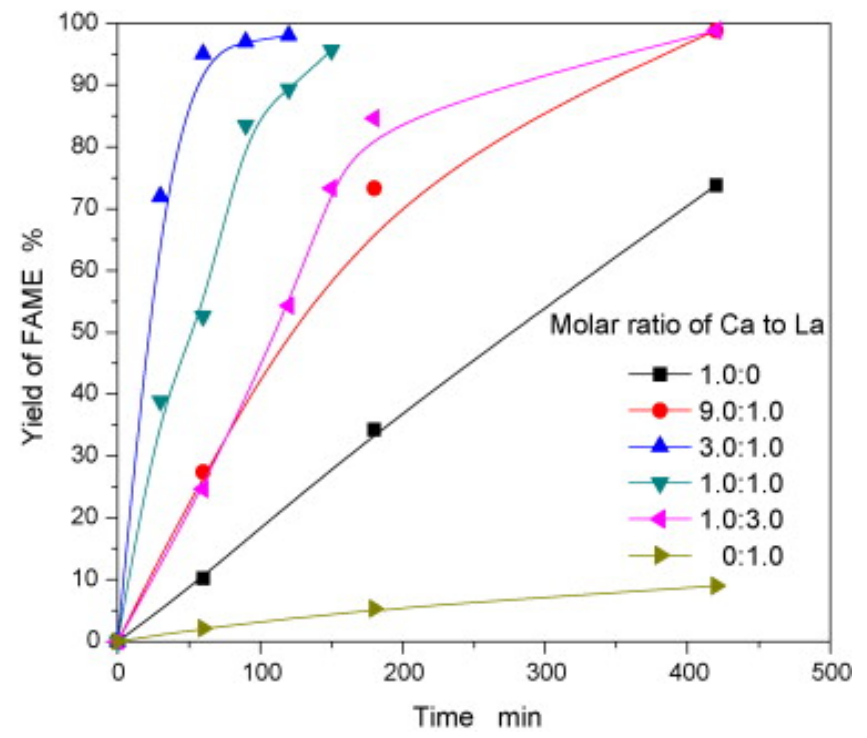

Fig. 7. Yield of FAME based on the catalysts with different molar ratio of Ca to La. Reaction conditions: $10 \mathrm{~g}$ of soybean oil, $7.6 \mathrm{~g}$ of methanol, $0.5 \mathrm{~g}$ of catalyst and $65^{\circ} \mathrm{C}$. 


\subsection{Effect of storage conditions}

Solid base catalysts are often vulnerable because they have a tendency to adsorb acid molecules from the ambient environment and lose activity [19]. As discussed in previous reports [38, 39], $\mathrm{CO}_{2}$ and $\mathrm{H}_{2} \mathrm{O}$ in air can easily poison basic sites on a catalyst surface and change the bulk crystal structure of the catalyst. However, information on the proper storage conditions for these types of the catalyst has not been reported. The effects of exposing the fresh catalysts in air, soybean oil and methanol on the activity of were investigated. The catalyst exposed to soybean oil showed a reaction rate very similar to that of freshly activated Ca3La1 catalyst (Figure 8). The catalysts exposed to methanol and air showed a significant decrease in catalytic activity. These findings suggest that active base sites on Ca3La1 can be effectively protected from acidic gas in air since soybean oil is non-polar and has a relatively low pKa value (3.55). On the other hand, methanol has a high pKa value (15.54) with dissolved acidic gases. Thus, these soluble acidic gases may poison the basic sites and lead to a gradual loss in catalyst activity.

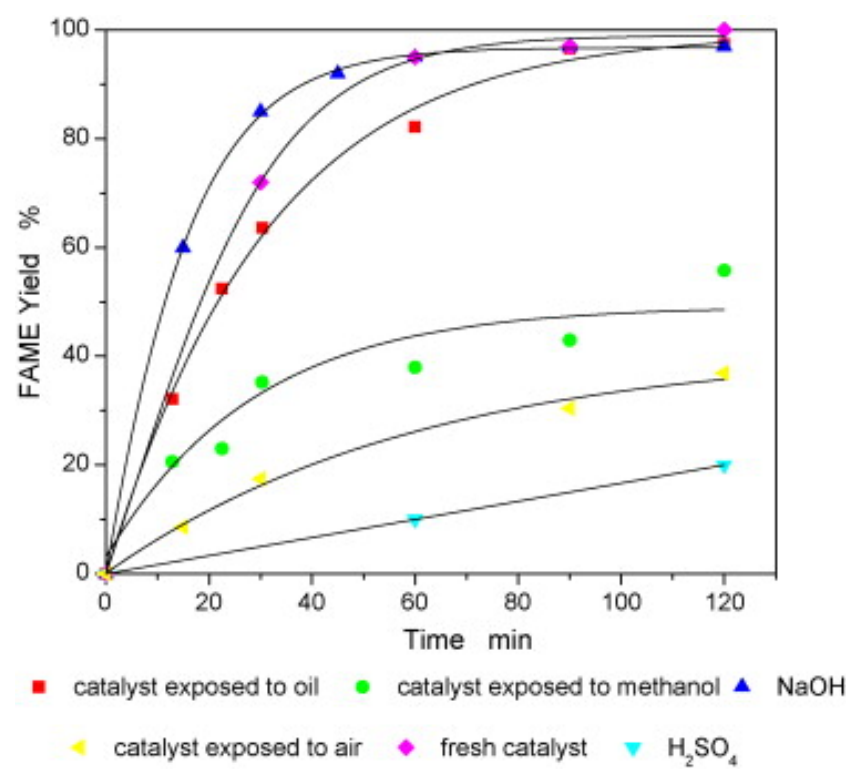

Fig. 8. Yield of FAME based on $\mathrm{H}_{2} \mathrm{SO}_{4}{ }^{(1)}, \mathrm{NaOH}^{(2)}$ and the catalysts stored in soybean oil, methanol and $\operatorname{air}^{(3)}$. Reaction conditions: (1) $20 \mathrm{~g}$ of soybean oil, $7.3 \mathrm{~g}$ of methanol, $0.6 \mathrm{~g}$ of $\mathrm{H}_{2} \mathrm{SO}_{4}$ and $65{ }^{\circ} \mathrm{C}$; (2) $20 \mathrm{~g}$ of soybean oil, $4.5 \mathrm{~g}$ of methanol, $0.2 \mathrm{~g}$ of $\mathrm{NaOH}$ and $65^{\circ} \mathrm{C}$; and (3) $10 \mathrm{~g}$ of soybean oil, $7.6 \mathrm{~g}$ of methanol, $0.5 \mathrm{~g}$ of catalyst and $65^{\circ} \mathrm{C}$. 


\subsection{Catalyst durability}

Ca3La1 catalyst was successfully recycled three times in a batch stir reactor (see Figure 9a), but its activity dropped in the fourth cycle. And in a continuous fix bed reactor the yield of FAME maintained higher than $92 \%$ for 14 days, but from the $15^{\text {th }}$ day catalyst deactivation can be observed (see Figure 9b). The deactivation of Ca3La1 catalyst was supposed to be related with the active site blockage by adsorbed intermediates or product species, such as diglyceride,

monoglyceride, and glycerin and the contamination by $\mathrm{O}_{2}, \mathrm{H}_{2} \mathrm{O}$, and $\mathrm{CO}_{2}$ in air as stated in 3.5 section [13, 33].Some researchers also suggested that the deactivation was caused by leaching of catalyst components especially for the calcium containing species [55, 56]. Further study about prolonging catalyst life should be done.
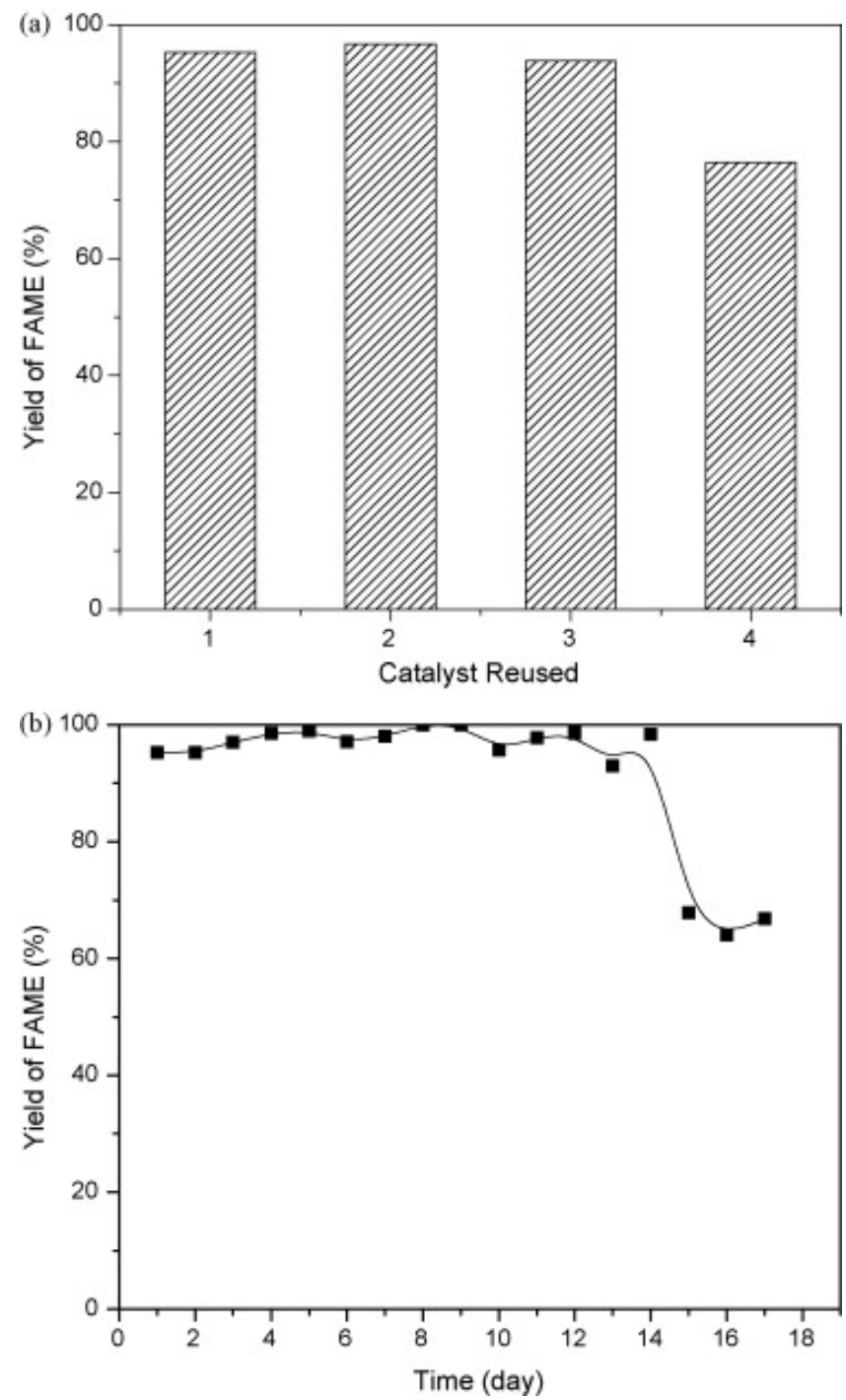

Fig. 9. Reusability of Ca3La1 catalyst. (a) In a batch stir reactor. Reaction conditions: $10 \mathrm{~g}$ of soybean oil, $7.6 \mathrm{~g}$ of methanol, $0.5 \mathrm{~g}$ of catalyst and $65^{\circ} \mathrm{C}$ and (b) in a fix bed continuous reactor. Reaction conditions: molar ratio of methanol to oil is 15:1, flow rate $0.2 \mathrm{~mL} / \mathrm{min}, 8 \mathrm{~g}$ of Ca3La1 catalyst, resident time $120 \mathrm{~min}$, $58^{\circ} \mathrm{C}$. 


\section{Conclusion}

A sequential precipitation method with ammonia solution, ethanol and carbon dioxide as precipitants for solid base catalyst preparation has been developed. A cooperative effect among the precipitants allows a more complete and uniform precipitation process, a higher specific BET surface area, higher concentration of strong base sites, and a high catalytic activity in the oil transesterification reaction for biodiesel production.

The structure of $\mathrm{Ca}$ and La metal oxides depends on the precipitation methods. Three types of Ca structures were observed: 1. Ca species segregated on the surface in the samples prepared by the ammonia-ethanol-carbon dioxide precipitation method and the physical mixing method. Crystal size of Ca species for Ca3La1 was smaller than of the CaO-La2O3. 2. Ca incorporated into the $\mathrm{La}(\mathrm{OH})_{3}$ lattice prepared by the impregnation method, 3.Ca stayed as a non-crystal structure prepared by the co-precipitation method. Segregated and highly dispersed Ca species were obtained by the ammonia-ethanol-carbon dioxide precipitation method.

The calcination temperature, nature of precipitants, $\mathrm{pH}$ value, and molar ratio of Ca to La have a significant effect on catalyst structure and activity. The Ca3La1 catalyst should be stored in nonpolar oil to prevent contamination and deactivation from ambient environment. Using this class of catalysts, which is relatively inexpensive because of low raw materials and manufacturing costs, significantly simplifies the product purification process, and greatly decreases the production cost of biodiesel.

\section{Acknowledgements}

Financial support from the Department of Energy (Grant DEFG36-05G085005) and Michigan's 21st Century Job Fund is gratefully acknowledged. 


\section{References}

[1] S.J. Clark, L. Wagner, M.D. Schrock, P.G. Piennaar, J. Am. Chem. Soc. 61 (1984) 16321638.

[2] P.R. Muniyappa, S.C. Brammer, H. Noureddini, Bioresour. Technol. 56 (1996) 19-24

[3] E. Crabbe, C. Nolasco-Hipolito, G. Kobayashi, K. Sonomoto, A. Ishizaki, Process Biochem. 37 (2001) 65-71.

[4] B. Freedman, E.H. Pryde, T.L. Mounts, J. Am. Oil. Chem. Soc. 61 (1984) 1638 -1643.

[5] F. Ma, L.D. Clements, M.A. Hanna, Trans ASAE 41 (1998) 1261 -1264.

[6] B. Narendra, D.C. Drown, K. Roger, H. Dwight, US. 1995.

[7] M. Canakci, J.V. Gerpen, Trans ASAE. 42 1203-1210.

[8] K. Ishihara, M. Nakayama, S. Ohara, H. Yamamoto, Tetrahedron. 58 (2002) 8179-8188.

[9] F. Omota, A.C. Dimian, A. Bliek, Chem. Eng. Sci. 58 (2003) 3175-3185.

[10] R.O. Chinta Reddy Venkat Reddy, and John G. Verkade, Energy Fuel. 20 (2006) 13101314.

[11] M.L. Granadosa, M.D.Z. Povesa, D.M. Alonsoa, R. Mariscala, F.C. Galisteoa, R. Moreno-Tosta, J.

Santamaríab, J.L.G. Fierroa, Appl. Catal. B: Environ. 73 (2007) 317-326

[12] X. Liu, X. Piao, Y. Wang, S. Zhu, H. He, Fuel. 87 (2008) 1076-1082

[13] S. Yan, H. Lu, B. Liang, Energy Fuel. 22 (2008) 646-651.

[14] M.C.G. Albuquerque, I. Jiménez-Urbistondo, J. Santamaría-González, J.M. Mérida-Robles, R. Moreno-

Tost, E. Rodríguez-Castellón, A. Jiménez-López, D.C.S. Azevedo, C.L.C. Jr.,

P. Maireles-Torres, Appl. Catal. A: Gen. 334 (2008) 35-43.

[15] H. Zhu, Z. Wu, Y. Chen, P. Zhang, S. Duan, X. Liu, Z. Mao, Chin J Catal. 27 (2006) 391-396.

[16] A. Kawashim, K. Matsubara, K. Honda, Bioresour. Technol. 99 (2008) 3439-3443

[17] C. Ngamcharussrivichai, P. Totarat, K. Bunyakiat, Appl. Catal. A: Gen. 341(2008)77-85.

[18] H. Wang, M. Wang, S. Liu, N. Zhao, W. Wei, Y. Sun, J. Mol. Catal. A: Chem. 258 (2006) 308-312.

[19] C.N. Satterfield, Heterogeneous Catalysis in Industrial Practice, McGraw-Hill, New York 1991.

[20] C. Marcilly, Acido-basic catalysis: application to refining and petrochemistry Paris, France: Editions

Technip, 2006.

[21] G. Jones, Organic Reactions, John Wiley, New York, 1967.

[22] D. Mao, G. Lu, Q. Chen, Appl. Catal.A: Gen. 263 (2004) 83-89

[23] J. March, Advanced Organic Chemistry, third ed., John Wiley, New York, 1985 [24] I. Chorkendorff, J.W.

Niemantsverdriet, Concepts of Modern Catalysis and Kinetics, WILEY-VCH Verlag GmbH \& Co.

KGaA, Weinheim, 2003.

[25] R. Sree, N.S. Babu, P.S. S.Prasad, Fure Process. Technol. 90 (2009) 152-157.

[26] Y. Liu, E. Lotero, J.G.G. Jr, X. Mo, Appl. Catal. A : Gen. 331 (2007) 138-148

[27] R.A. Santen, M. Neurock, Molecular Heterogeneous Catalysis, WILEY-VCH Verlag GmbH \& Co. KGaA, 2006.

[28] J. Tsuji, Transition Metal Reagents and Catalysts: Innovations in Organic Synthesis, John Wiley and Sons, 2002.

[29] L. Forni, Catal. Rev. 8 (1974) $65-115$ 
[30] J. Zhu, Y. Chun, Y. Wang, Q. Xu, Catal. Today. 51 (1999 ) 103-111.

[31] K. Wang, X. Wang, G. Li, Micropor. Mesopor. Mat. 94 (2006) 325-329.

[32] X. Li, G. Lu, Y. Guo, Y. Guo, Y. Wang, Z. Zhang, X. Liu, Y. Wang, Catal. Commun. 8 (2007) 1969-1972

[33] H. Gorzawski, W.F. Hoelderich, Appl. Catal. A: Gen. 179 (1999) 131-137.

[34] S.M.d. Lima, M.A. Peña, J.L.G. Fierro, J.M. Assaf, Catal. Lett. 124 (2008) 195-203.

[35] P. Kaszner, M. Baerns, Appl. catal. A: Gen. 139 (1996) 107-129.

[36] J.V. Gerpen, Fuel Process. Technol. 86 (2005) 1097 -1107.

[37] H.E. Hoydonckx, D.E. Vos, S.A. Chavan, Top. Catal. 27 (2004) 83 -96.

[38] S. Yan, S.O. Salley, K.Y.S. Ng, Appl. Catal. A: Gen. 353 (2009) 203-212.

[39] S. Yan, M. Kim, S.O. Salley, K.Y.S. Ng, Appl. Catal. A: Gen. 360 (2009) 163-170.

[40] J.H. Song, J.H. Zhang, M. Xu, W. Dong, S.H. Guo, Chin. J. Chem. 25 (2005) 959-963.

[41] R.D. Srivastava, Heterogeneous Catalytic Science, CRC Press: Boca Raton, FL, 1988.

[42] J.H. Boer, The Mechanism of Heterogeneous Catalysis, Elsevier, Amsterdam, 1960.

[43] Y.C. Xie, Y.Q. Tang, Adv. Catal. 37 (1990) 1-43.

[44] S.M.d. Lima, M.A. Peña, J.L.G. Fierro, J.M. Assaf, Catal. Lett. 124 (2008) 195-203.

[45] P. Liu, T. Kendelewicz, G.E. Brown, G.A. Parks, P. Pianetta, Surf. Sci. 416 (1998) 326.

[46] Crespin M., Hall W. K., J. Catal. 69 (1981) 359.

[47] C.S. Doyle, T. Kendelewicz, X. Carrier, G.E. Brown, Surf. Rev. Lett. 6 (1999) 1247.

[48] V.E. Henrich, P.A. Cox, The Surface Science of Metal Oxides, Cambridge University Press, Cambridge, 1994.

[49] J.V. Gerpen, Fuel Process. Technol. 86 (2005) 1097-1107.

[50] H.E. Hoydonckx, D.E. Vos, S.A. Chavan, Top. Catal. 27 (2004) 83-96.

[51] S.L.P. Dale L. Perry, Handbook of Inorganic Compounds, CRC Press, 1995.

[52] J. Hagen, Industrial Catalysis: A Practical Approach, Wiley-VCH, 2006.

[53] K. Tanabe, M. Misono, Studies in the Surface Science and Catalysis, Elsevier, Amsterdam, 1989.

[54] G.C. Bond, Heterogeneous Catalysis: Principles and Applications 2 Sub edition ed., Clarendon Pr, 1987.

[55] M. Kouzu, T. Kasuno, M. Tajika, Y. Sugimoto, S. Yamanaka, J. Hidaka, Fuel. 87 (2008) 2798-2806.

[56] M. Kouzu, S. Yamanaka, J. Hidaka, M. Tsunomori, Appl. Catal. A: Gen. 355 (2009) 94-99. 